\title{
A NEW SPECIES OF STRATIODRILUS (POLYCHAETA, HISTRIOBDELLIDAE) FROM FRESHWATER CRAYFISHES OF SOUTHERN BRAZIL ${ }^{1}$
}

\author{
J. F. R. Amato
}

\begin{abstract}
A new species of polychaete, Stratiodrilus vilae, epizoic on Parastacus brasiliensis (von Martens, 1869) and P. defossus Faxon, 1898, is described from the State of Rio Grande do Sul, southern Brazil. The new species has one pair of long, anal, conical ventral lobes, one on each side of the anus, claspers in the males, and one pair of tubercles in each of the posterior locomotor appendages; and the jaw apparatus not reaching the limit between the head and the first segment.
\end{abstract}

KEYWORDS. Histriobdellidae, Stratiodrilus, Parastacidae, Parastacus, southern Brazil.

\section{INTRODUCTION}

Histriobdella van Beneden, 1858, found on eggs of lobsters in Europe and in North America, Stratiodrilus Haswell, 1900, found in the branchial chamber of freshwater crayfishes in Australia, Madagascar and South America, and Dayus Steiner \& Amaral, 1999 , collected from the pleopods of a marine isopod in South Africa are the three genera of epizoic, ectocommensal polychaetes in Histriobdellidae.

The genus Stratiodrilus has nine species described to the present time. Stratiodrilus tasmanicus described by Haswell (1900) occurring on Astacopsis franklinii (Gray) and A. franklinii var. tasmanicus Erickson, in Tasmania, Australia; Stratiodrilus novaehollandiae described by Haswell (1913), epizoic on A. serratus Shaw, from New

1. Contribuição 354 do Departamento de Zoologia, UFRGS.

2. Departamento de Zoologia, Universidade Federal do Rio Grande do Sul (UFRGS), Porto Alegre, RS, 90040-060, Brasil (jfra@vant.com.br). 
South Wales, Australia; Stratiodrilus haswelli described by HARRISON (1928), epizoic on Astacoides madagascariensis (Milne Edwards \& Audouin, 1839) from Madagascar, were the first species identified in the genus. CORDERO (1927) described Stratiodrilus platensis on Aegla laevis (Latreille, 1818) (probably A. platensis Schmitt, 1942 or A. uruguayana Schmitt, 1942), from Uruguay. VILA \& BAHAMONDE (1985) described two additional species of Stratiodrilus, S. aeglaphilus on A. laevis laevis (Latreille, 1818) and S. pugnaxi on Parastacus pugnax (Poepigg, 1835) from Chile and presented a key for the six species known to that date. Stratiodrilus arreliai described by Amaral \& Morgado (1997), on Aegla perobae Hebling \& Rodrigues, 1972, collected in the State of São Paulo was the first species described from Brazil. The authors published diagrammatic illustrations of the posterior locomotor appendages of all species of Stratiodrilus, showing that the pair of $\mathrm{C} 4$, the associated conical ventral lobes, and the tubercles were some of the most important specific characters. Steiner \& Amaral (1999) made the first revision of Histriobdellidae, proposing the genus Dayus to accomodate Stratiodrilus cirolanae described by FüHR (1971), from South Africa and described two species of Stratiodrilus, S. robustus epizoic on Trichodactylus sp., from São Paulo and S. circensis on Aegla sp. (probably A. schmitti Hobbs III) from the State of Paraná.

Dioni (1972) recorded S. platensis on undetermined specimens of Aegla and Parastacus from Argentina while Moyano et al. (1993) recorded the same species in Chile on Aegla bahamondei Jara, 1982 and A. abtao Schmitt, 1942. LaNg (1949) has carried out the only histological study on any species of Stratiodrilus and Roubaud (1962) has presented the most comprehensive description and illustrations of the jaw apparatus using S. platensis. Moyano et al. (1993), while reviewing the Chilean species of Stratiodrilus, included an undetermined species of Stratiodrilus, epizoic on A. laevis, from Rio Valdivia (Dr. Irma Vila, pers. comm.).

A new species of Stratiodrilus has been found on two species of freshwater crayfish Parastacus brasiliensis and P. defossus in the State of Rio Grande do Sul, southern Brazil, which is described.

\section{MATERIAL AND METHODS}

Specimens of $P$. brasiliensis were collected from a tributary of the Mineiro creek, Taquara, State

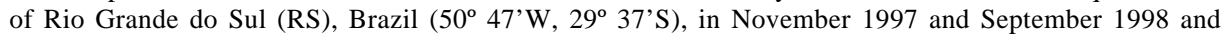
from an unidentified creek of Mariana Pimentel (RS) (30 $\left.21^{\prime} \mathrm{S}, 51^{\circ} 35^{\prime} \mathrm{W}\right)$, in January of 1998 . One specimen of $P$. defossus was collected from a swampy area in Mariana Pimentel in March 1998. The annelids were collected after immersion of the crayfish in water with menthol, to prevent body contraction, and were fixed in A. F. A. (70\% ethanol, formalin 37\%, glacial acetic acid). Some specimens were cleared in Amann's lacto-phenol (HUMASON, 1972) and beech wood creosote; others were stained in Delafield's hematoxylin; all specimens were mounted in Canada balsam. Photomicrographs were taken using Kodak Gold 100 ISO film. Measurements are in micrometers $(\mu \mathrm{m})$, unless otherwise indicated; the range for each character is followed between parentheses by the arithmetic mean the indication of sample size, when the number measured is different from that stated at the beginning of the description, and the standard deviation.

The type specimens were deposited in the Coleção Helmintológica, Instituto Oswaldo Cruz (CHIOC), Rio de Janeiro (RJ), Brazil: 9 holotype, CHIOC 34334a; $\sigma^{-1}$ allotype CHIOC 34334b; paratypes CHIOC 34335a-f. Some paratypes were also deposited in the United States National Museum (USNM), Smithsonian Institution, Washington, D.C., U.S.A.: USNM 186786-186791. One male and one female of Stratiodrilus arreliai Amaral \& Morgado, 1997, from the personal collection of Dr. A. Cecília Z. Amaral, were also examined. 

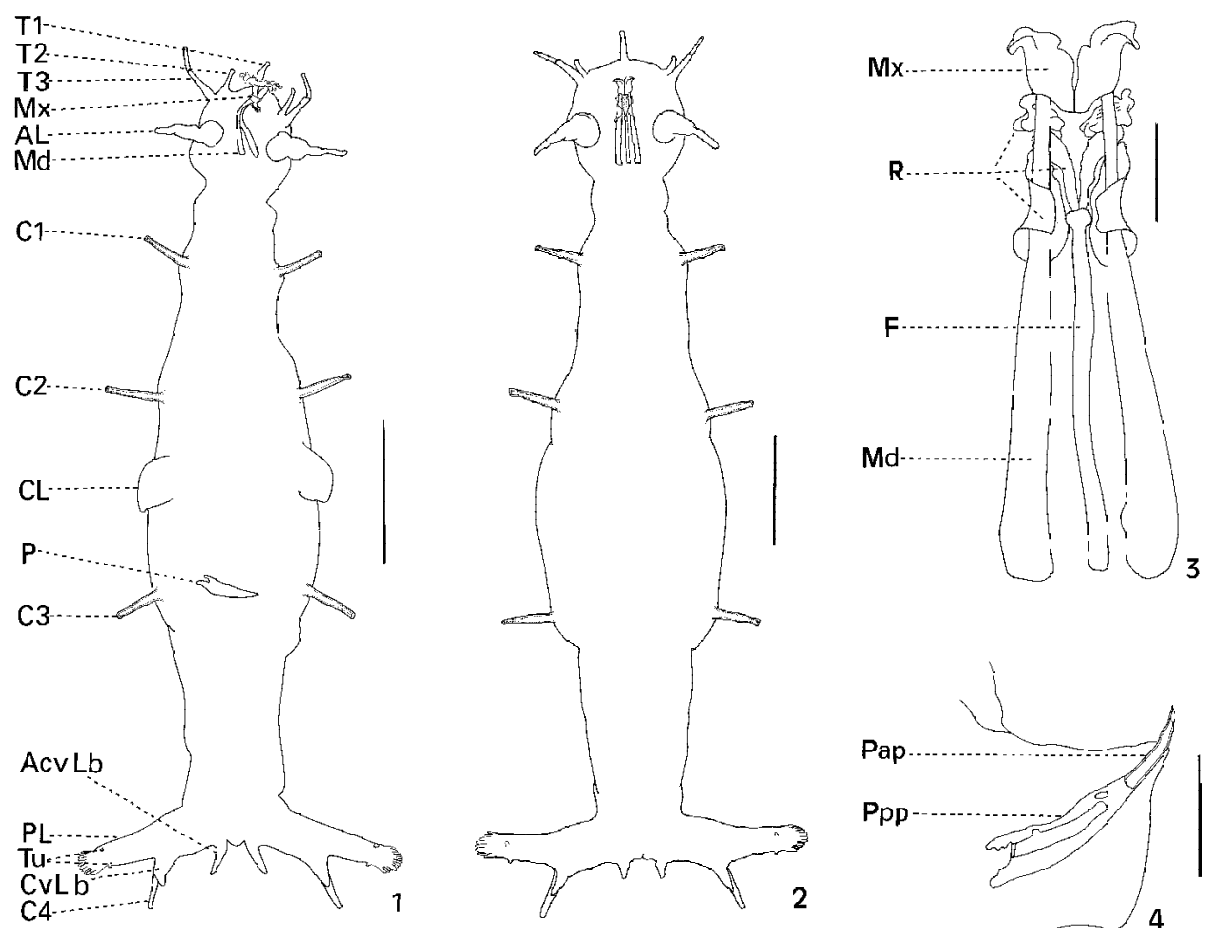

Figs. 1-4. Stratiodrilus vilae sp. nov.: $1, \sigma^{-}$, allotype, ventral view, with the jaw apparatus everted; 2,9 , holotype, ventral view; 3, jaw apparatus; 4, penis. (AcvLb, anal, conical, ventral lobe; AL, anterior locomotor appendage; $\mathrm{C} 1-\mathrm{C} 3$, lateral cirri; $\mathrm{C} 4$, cirrus 4; $\mathrm{CL}$, clasper; $\mathrm{CvLb}$, conical ventral lobe; F, fulcrum; Md, pair of mandibles; Mx, maxillae; P, penis; PL, posterior locomotor appendage; Pap, anterior portion; Ppp, posterior portion; R, rami, in normal position; Tu, tubercles; T1-T3, antennae). Scale bars: $0.2 \mathrm{~mm}$, fig. $1 ; 30 \mu \mathrm{m}$, figs. 2,$3 ; 50 \mu \mathrm{m}$, fig. 4 .

\section{Stratiodrilus vilae sp. nov.}

(Figs. 1 - 18)

Description (based on 18 mounted specimens): $\sigma^{\prime}(\mathrm{n}=5)$ (figs. 1, 10-14) 1.07-1.11 mm in total body length $(1.08 \mathrm{~mm} ; 32.09) ; 209$ - 279 wide $(239 ; 26.81)$. Head 150 - 166 long $(163 ; 7.46)$ with five antennae; median antenna (T1) with similar length as first lateral pair (T2), both unsegmented; second lateral pair (T3) bisegmented, collapsible, with tips dilated; one pair of ventral anterior locomotor appendages (AL), retractile, with the tips dilated. Three pairs of lateral, unsegmented cirri (C1, C2, C3) (fig. 1), with a central canal and an opening at the tip. Posterior locomotor appendages (PL) 438 - 449 long $(448 ; 10.68)$, with a pair of posterior cirri $\mathrm{C} 4$ (fig. 1) and an adjacent conical, ventral lobe (CvLb, fig. 1) of different structure than the cirri; one pair of anal, conical, ventral lobes (AcvLb, figs. 1, 10); each posterior locomotor appendage with one pair of tubercles (Tu, fig. 14, arrow heads). Jaw apparatus (figs. 3, 11) heavily chitinous, $128-155$ long (147; $\mathrm{n}=4$; $\mathrm{SD}=13.23$ ), 

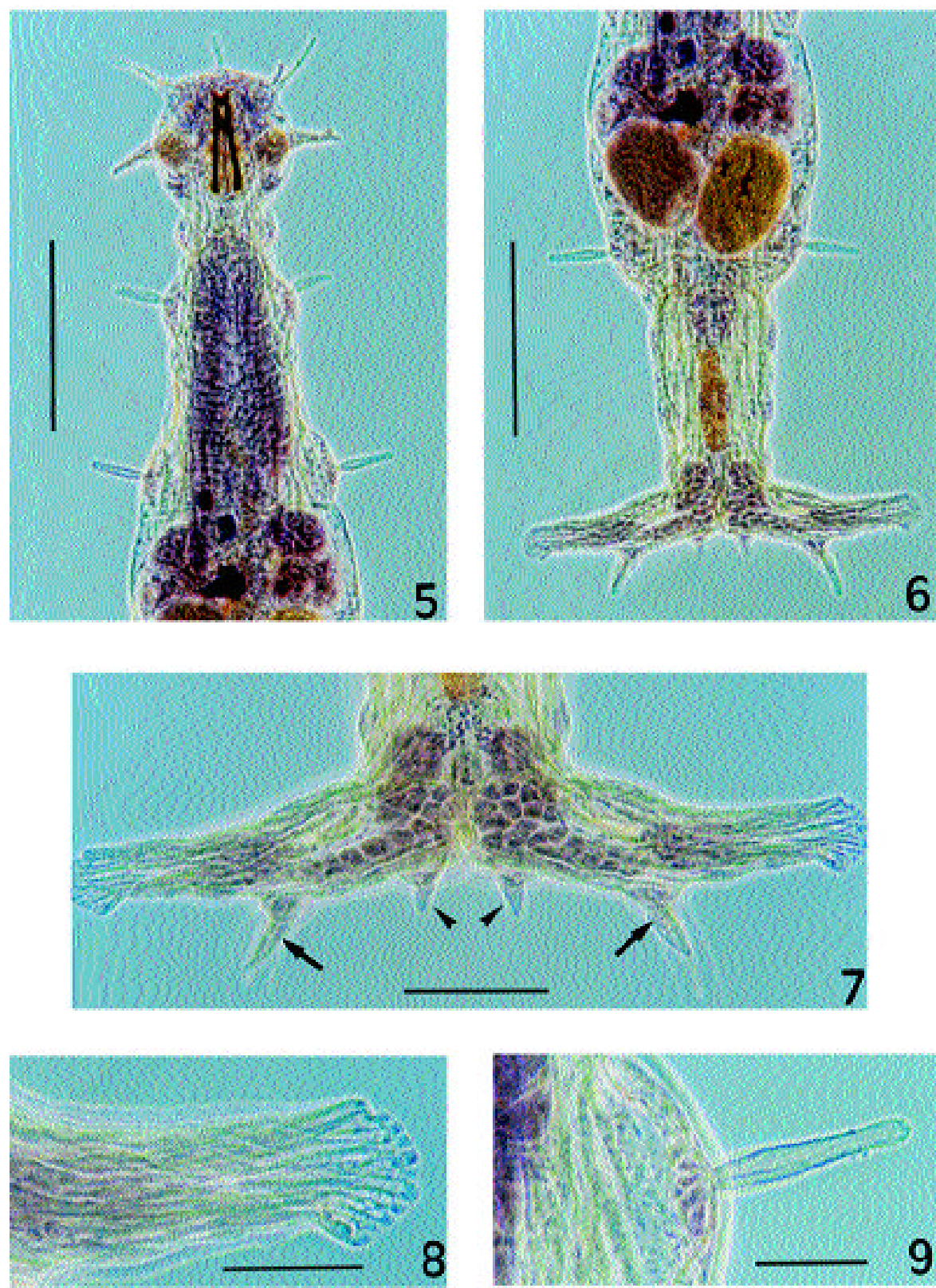

Figs. 5-9. Stratiodrilus vilae sp. nov.: 9 , holotype: 5, anterior half; 6, posterior half; 7, posterior locomotor appendages; 8, extremity of posterior locomotor appendage; 9, cirrus 2 (AcvLb, anal, conical, ventral lobes, small arrow heads; CvLb, conical ventral lobes, large arrows). Scale bars: $300 \mu \mathrm{m}$, figs. 5,$6 ; 100 \mu \mathrm{m}$, fig. $7 ; 50 \mu \mathrm{m}$, figs. 8,9 . 

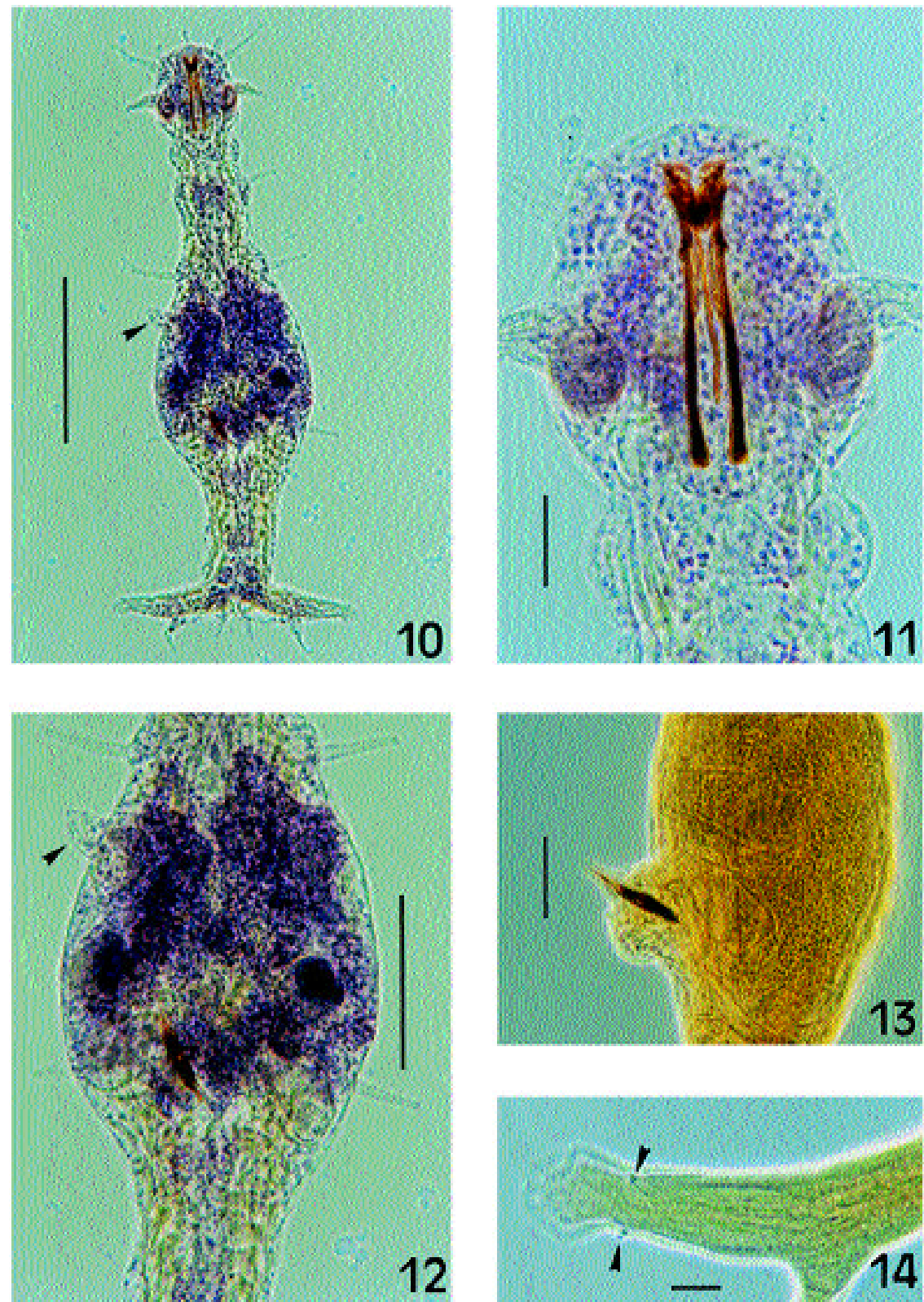

Figs. 10-14. Stratiodrilus vilae sp. nov. $\sigma^{\circ}$, allotype: 10, entire specimen, right clasper, small arrow head; 11, head, jaw apparatus; 12, central portion of body with right clasper, small arrow head; 13, unstained male, showing penis; 14 , posterior locomotor appendage, focusing the tubercles, small arrow heads. Scale bars: $300 \mu \mathrm{m}$, fig. $10 ; 50 \mu \mathrm{m}$, fig. $11 ; 300 \mu \mathrm{m}$, fig. $12 ; 300 \mu \mathrm{m}$, fig. $13 ; 20 \mu \mathrm{m}$, fig. 14 . 
with a pair of mandibles, four maxillae and one fulcrum, thinner than mandibles, with length similar to the mandibles; when the rami are not everted; and a middle portion composed of four rami (R, fig. 3), with complex morphology, composed of a number of small pieces (R, figs.1,3). Penis (figs. 4, 13), heavily chitinous, articulated, with tip in bezel, and a central duct, 82 - 112 in total length (101; 12.86); distal portion (Pap, fig. 4), 25 - 35 long $(31 ; 4.84)$; proximal portion (Ppp, fig. 4) wider. Claspers present (CL, figs 1, 9-10, arrow heads), when not retracted into lateral pouches, $40-74$ long $(54 ; 17.91)$.

Female ( $\mathrm{n}=10$ ) (figs. 2, 5-9, 15-18): $0.89-1.53 \mathrm{~mm}$ in total body length $(1.09 \mathrm{~mm}$; 164.24), 167 - 376 wide $(220 ; 60.13)$. Head 155 - 222 long $(168 ; 19.94)$. Posterior locomotor appendages 416 - 633 long (483; 57.54). Jaw apparatus 128 - 167 long (146; 12.02), not reaching trunk; fulcrum $74-107$ long $(88 ; n=3 ; 16.87)$. Number of eggs per female, $0-3$ (figs. 15-17).

Diagnosis. Stratiodrilus vilae sp. nov. has one pair of long, anal, conical, ventral lobes (AcvLb); the cirrus 4 single, adjacent to a long conical ventral lobe $(\mathrm{CvLb})$; claps in the males; one pair of tubercles in each of the posterior locomotor appendages; and the jaw apparatus not reaching the limit between the head and the first segment.

Type host: Parastacus brasiliensis (von Martens, 1869) and Parastacus defossus Faxon, 1898. In the branchial chamber. Type locality, Taquara, RS, Brazil.

Etymology. The specific epithet vilae was given in honor of Dr. Irma Vila, of the Universidad de Santiago, Chile, who has described the first species of Stratiodrilus from Chile.

Discussion. Stratiodrilus vilae differs from all species of Stratiodrilus, except $S$. pugnaxi for having one pair of long, anal, conical, ventral lobes (AcvLb), which STEINER \& AmAral (1997) called C5. Stratiodrilus pugnaxi has a double pair of long, anal, conical, ventral lobes (AcvLb). Stratiodrilus sp. has one pair of AcvLb as S. vilae. Stratiodrilus vilae differs from all species of Stratiodrilus known to date, except $S$. circensis and Stratiodrilus sp. of Moyano et al. (1993), for having one pair of tubercles in each of the posterior locomotor appendages. The tubercles are absent in $S$. tasmanicus, $S$. novaehollandiae, $S$. platensis, and $S$. robustus, while they are single in $S$. haswelli, $S$. aeglaphilus, $S$. pugnaxi, and $S$. arreliai, and two pairs in $S$. circensis and Stratiodrilus sp. of MOYANo et al. (1993).

According to the pictorial keys given by MoYano et al. (1993) and by Amaral \& Morgado (1997), it is possible to see that $S$. tasmanicus and $S$. novaehollandiae lack the pair of anal, conical, ventral lobes (AcvLb) called cirrus $\mathrm{C} 5$ by some authors, including Steiner \& Amaral (1997). To treat the conical lobes present in the posterior locomotor appendages, both the CvLb and the AcvLb as cirri is an unwarranted action as the nature of these structures is completely different, as can be seen in figs. 7, 9. Using this approach none of the species of Stratiodrilus presents a cirrus denominated C5 by these authors. Using the same reasoning $\mathrm{C} 4$ cannot be "double". It might, in some species, be associated with an adjacent conical, ventral lobe $\mathrm{CvLb}$. There are species in which C4 lacks the adjacent conical, ventral lobe (CvLb). This character is shared by $S$. haswelli, $S$. aeglaphilus, and S. arreliai. 



Figs. 15-18. Stratiodrilus vilae sp. nov. 9 : 15 , paratype with one egg; 16, holotype with two eggs; 17 , paratype with three eggs; 18, close-up of ovaries, arrows. Scale bars: $300 \mu \mathrm{m}$, fig. $15 ; 300 \mu \mathrm{m}$, fig. 16; $300 \mu \mathrm{m}$, fig. $17 ; 50 \mu \mathrm{m}$, fig. 18 . 
Acknowledgments. To Drs. Georgina Bond-Buckup and Ludwig Buckup (UFRGS), for collecting and identifying the crayfish from Taquara; to Alexandre O. de Almeida, M. Sc., UFRGS, for collecting the crayfish from Mariana Pimentel; to Dr. A Cecília Z. Amaral, Universidade Estadual de Campinas, for the loan of specimens of S. arreliai; to Dr. Irma Vila, Universidad de Santiago, Chile, for the kindness of receiving us in Santiago, for the reprint of her paper on Stratiodrilus, photographs and drawings of other species of Stratiodrilus; to Dr. Hugo I. Moyano G., Universidad de Concepción, Chile, for the reprint of his paper; to Dr. Linda Ward (USNM), for the kindness of sending the CD with the world literature on polychaetes and for accepting paratypes to be deposited in the Polychaeta Collection; to Prof. Abner Chiquieri, Universidade Federal Rural do Rio de Janeiro (UFRRJ), Seropédica (RJ), for his advise on the correct formation of the specific name for the new species; to Dr. David E. Evans, UFRRJ, for revising the English version of the manuscript; and to CNPq, Brazil, for the Senior Visiting Research Fellowship, in the Department of Zoology, UFRGS.

\section{REFERENCES}

Amaral, A. C. Z. \& Morgado, M. H. 1997. Stratiodrilus (Annelida: Polychaeta: Histriobdellidae) associated with a freshwater decapod, with the description of a new species. Proc. biol. Soc. Wash., Lawrence, 110(3):471-475.

Cordero, E. H. 1927. Un nuevo Arquianélido, "Stratiodrilus platensis" n. sp., que habita sobre "Aegla laevis" (Latr.). Nota preliminar. Physis, Buenos Aires, 8:574-578.

DionI, W. 1972. Didymorchis, Temnocephala (Platyhelmintha) y Stratiodrilus (Annelida) vermes epizoicos sobre Aegla y Parastacus (Crustacea: Decapoda) de lagos andino-patagonicos. Notas taxinomicas y biogeograficas. Acta Zool. lilloana, Tucumán, 29:167-179.

FüHR, I. M. 1971. A new histriobdellidae on a marine isopod from South Africa. S. Afr. Jl. Sci., Pretoria, 67:325-326.

HARRISON, L. 1928. On the genus Stratiodrilus (Archiannelida: Histriobdellidae), with a description of a new species from Madagascar. Rec. Aust. Mus., Sydney, 16:116-121.

Haswell, W. A. 1900. On a new Histriobdellidae. Q. JI microsc. Sci., London, 59:91-99.

1913. Notes on Histriobdellidae. Q. JI microsc. Sci., London, 43:299-335.

Humason, G. 1972. Animal Tissue Techniques. 3. ed. San Francisco, W. H. Freeman, 641p.

LANG, K. 1949. A contribution to the morphology of Stratiodrilus platensis Cordero (Histriobdellidae). Ark. Zool., Uppsala, 42(23):1-30.

Moyano, H. I.; Carrasco, F. \& Gacitua, S. 1993. Sobre las especies chilenas de Stratiodrilus Haswell, 1900 (Polychaeta, Histriobdellidae). Boln Soc. Biol. Concepción, Concepción, 64:147-157.

Roubaud, G. 1962. Recherches sur les Stratiodrilus platensis Cordero, Archiannélides, parasites des Aegla des lacs de Patagonie. In: Debouteville, C. D. \& Rapoport, E. eds. Biologie de l'Amérique Australe. Paris, Centre National de la Recherche Scientifique. v.1, p. 231-254.

Steiner, T. M. \& Amaral, A. C. Z. 1999. The family Histriobdellidae (Annelida, Polychaeta) including descriptions of two new species from Brazil and a new genus. Contrib. Zool., Amsterdam, 68(2): 95-108.

Vila, I. \& Bahamonde, N. N. 1985. Two new species of Stratiodrilus. S. aeglaphilus and S. pugnaxi (Annelida: Histriobdellidae) from Chile. Proc. biol. Soc. Wash., Lawrence, 98(2):347-350.

Recebido em 08.03.2000; aceito em 06.11.2000.

Iheringia, Sér. Zool., Porto Alegre, (90): 37-44, 25 de maio de 2001 